\title{
Desensitization of the dopaminergic system in bovine retina following incubation with high potassium
}

\author{
Janice M. Ackerman ${ }^{1, *}$ and Margaret E. Gnegy ${ }^{2}$ \\ ${ }^{\prime}$ Neuroscience Program and ${ }^{2}$ Department of Pharmacology, University of Michigan Medical School, Ann Arbor, MI 48109-0626 (U.S.A.)
}

(Accepted 16 January 1990)

Key words: Desensitization; Dopamine $\mathrm{D}_{1}$; Retina; Potassium stimulation

\begin{abstract}
The effect of potassium depolarization on dopamine $\mathrm{D}_{1}$ receptor activity in bovine retina was investigated. Preincubation of bovine retinas in buffer containing high $\mathrm{KCl}(56 \mathrm{mM})$ as compared to a low $\mathrm{KCl}$ control buffer resulted in a significant decrease in dopamine-stimulated adenylate cyclase activity with no change in basal or GTP-stimulated adenylate cyclase activity. The apparent $V_{\text {max }}$ for dopamine was decreased from $102 \pm 15 \mathrm{pmol} / \mathrm{min} / \mathrm{mg}$ protein in retinas preincubated in high $\mathrm{KCl}$ to $71 \pm 11 \mathrm{pmol} / \mathrm{min} / \mathrm{mg}$ protein in control retinas $(n=5)$. The apparent $K_{\mathrm{a}}$ for dopamine stimulation of the enzyme did not change. The potassium-induced desensitization could be blocked by preincubation with the dopamine antagonist cis-flupenthixol suggesting that the desensitization was caused by the release of dopamine. The rapid desensitization was not accompanied by a change in $D_{1}$ receptor density as assessed by binding of $\left[{ }^{3} \mathrm{H}\right] \mathrm{SCH} 23390$ nor in agonist binding as assessed by competition of the selective $\mathrm{D}_{1}$ agonist, SKF38393, for $\left[{ }^{3} \mathrm{H}\right] \mathrm{SCH} 23390$ binding. The potassium-induced desensitization was mimicked by preincubation of retinas in control medium containing isobutylmethylxanthine or dibutyryl cyclic AMP. Incubation of retinas in $56 \mathrm{mM} \mathrm{KCl}$ also led to a decrease in activation of adenylate cyclase by vasoactive intestinal polypeptide. These results strongly suggest that potassium depolarization leads to a very rapid heterologous desensitization of adenylate cyclase in bovine retinas.
\end{abstract}

\section{INTRODUCTION}

Dopamine (DA) has been well established as a neurotransmitter in the retina and this tissue has been extensively used to investigate the DA neurotransmitter system. DA-containing neurons are located among the amacrine cells in the inner nuclear layer of the retina ${ }^{7}$. DA $D_{1}$ receptors present in the inner retina stimulate adenylate cyclase activity ${ }^{4,26}$. Electrophysiological studies have shown that DA affects the receptive field properties of ganglion cells in mammalian retina ${ }^{1,30,32}$. In rabbit retina, $D_{1}$ receptor antagonists were found to affect the spontaneous activity of on- and off-center ganglion cells and to abolish the antagonist surround ${ }^{11,12} . D_{1}$ receptors have also been shown to mediate acetylcholine release in mammalian retina ${ }^{9}$. In fish retinas, $D_{1}$ receptor activation has been shown to uncouple electrical synapses between horizontal cells ${ }^{31}$.

DA has been shown to be released from its neurons in retina in response to light ${ }^{2.15}$. DA released in response to light could act at postsynaptic $D_{1}$ receptors and subsequently alter the responsiveness of that receptor. In previous studies, we found a rapidly-occurring desensitization of DA-stimulated adenylate cyclase activity in membrane fractions of bovine retina that occurred after preincubation of the retinas under light as compared to dark conditions ${ }^{6}$. The desensitization was manifested as a significant decrease in the apparent $V_{\max }$ for DA, with no change in the apparent $K_{\mathrm{a}}$. Preincubation of the retinas with $\mathrm{DA}$ produced a desensitization of the DA-stimulated adenylate cyclase activity that resembled that of light, supporting the conclusion that release of DA mediated the light-induced desensitization of the enzyme activity.

One caveat to those experiments is that rhodopsin could not be continuously regenerated in the isolated bovine retina under the preincubation conditions. In order to further investigate the molecular mechanism of the desensitization of the $D_{1}$ receptor in bovine retina, a depolarizing concentration of potassium was used to release DA. Incubation of retinas with depolarizing concentrations of potassium has been shown to release DA and increase cAMP content in mammalian, amphibian and fish retinas ${ }^{2,5,25}$. The increase in cAMP can be blocked by DA receptor antagonists ${ }^{5,28}$, further demonstrating that $\mathrm{K}^{+}$depolarization releases $\mathrm{DA}$.

In this report, we demonstrate a rapid desensitization of DA-sensitive adenylate cyclase in mammalian retinas in response to potassium-induced depolarization. We then examine whether the desensitization is due to a

\footnotetext{
* Present address: Lafayette Clinic - NPPL, 951 E. Lafayette, Detroit, MI 48207, U.S.A.

Correspondence: M.E. Gnegy, 7427 Medical Science I, University of Michigan Medical School, Ann Arbor, MI 48109-0626, U.S.A.
} 
change at the level of the receptor or an alteration in the coupling of the receptor to adenylate cyclase. Our studies indicate that potassium depolarization leads to a desensitization of adenylate cyclase activity that is not specific for DA. The results are compatible with development of heterologous desensitization which is due to an uncoupling of receptors from the stimulatory GTP-binding protein, $\mathrm{Gs}^{8,27}$.

\section{MATERIALS AND METHODS}

\section{Tissue treatment}

Bovine eyes were obtained from a slaughterhouse shortly after the animals' death, maintained in the dark and transported on ice. Retinas were dissected from the eyes in a dark room under a dim red light (Kodak Adjustable Safelight Lamp Model B). The eye was hemisected, and the back of the eyeball was inverted, releasing the vitreous humor. The retina was gently removed from the underlying choroid and sclera using forceps and placed in physiological buffer.

\section{Treatment with high potassium}

The physiological buffer used contained $30 \mathrm{mM}$ HEPES buffer, $\mathrm{pH} 7.4,1.7 \mathrm{mM} \mathrm{CaCl}, 2.9 \mathrm{mM} \mathrm{NaHCO} 3,1.0 \mathrm{mM} \mathrm{MgCl}_{2}, 1 \mathrm{mg} / \mathrm{ml}$ glucose, $\mathrm{KCl}$ and $\mathrm{NaCl}$. The buffer for high potassium treatment contained $56 \mathrm{mM} \mathrm{KCl}$ and $91.6 \mathrm{mM} \mathrm{NaCl}$, while buffer for control retinas contained $5.6 \mathrm{mM} \mathrm{KCl}$ and $142 \mathrm{mM} \mathrm{NaCl}$. Incubations were conducted for $15 \mathrm{~min}$ at $37^{\circ} \mathrm{C}$ in the dark room immediately after dissection of retinas. Retinas were placed in previously oxygenated control or treatment buffer in airtight plastic tubes in a ratio of 0.75 $\mathrm{ml}$ buffer per retina. The reaction was stopped by diluting the tissue with 4 vols. of the buffer used for adenylate cyclase or binding assays. The tissue was centrifuged and washed 3 times with the appropriate buffer. Treatment groups were paired within a given experiment to minimize errors associated with interassay variability.

\section{Adenylate cyclase assays}

Membrane fractions were prepared by homogenizing the tissue in 10 vols. of $20 \mathrm{mM}$ HEPES buffer, $\mathrm{pH} 7.5$, containing $1.2 \mathrm{mM}$ EGTA and $5 \mathrm{mM} \mathrm{MgSO}_{4}$ in a glass teflon homogenizer. The homogenate was centrifuged at $27,000 \mathrm{~g}$ for $20 \mathrm{~min}$ and washed twice. The resulting pellet was resuspended in the HEPES buffer. The assay, in a volume of $200 \mu \mathrm{l}$, contained $20 \mathrm{mM}$ HEPES, pH 7.5 , $5 \mathrm{mM} \mathrm{MgCl}_{2}, 2 \mathrm{mM}$ cAMP, $4 \mathrm{mM}$ phosphenolpyruvate (PEP), 20 $\mu \mathrm{g}$ pyruvate kinase, $0.12 \mathrm{mM}$ isobutylmethylxanthine (IBMX), 0.5 $\mathrm{mM}\left[\alpha-{ }^{32} \mathrm{P}\right] \mathrm{ATP}(1 \mu \mathrm{Ci} /$ assay), and $25 \mu \mathrm{l}$ of particulate membrane fraction to give a protein concentration of $0.1 \mathrm{mg} / \mathrm{ml}$, with or without the addition of $1 \mu \mathrm{M}$ GTP, DA or vasoactive intestinal polypeptide (VIP). DA- or VIP-stimulated adenylate cyclase activities were calculated as the $\mathrm{pmol}$ of $\mathrm{cAMP} / \mathrm{min} / \mathrm{mg}$ protein produced above that activity in the presence of GTP alone. Assays were incubated for $8 \mathrm{~min}$ at $37^{\circ} \mathrm{C}$ and the reaction was stopped by heating for $1 \mathrm{~min}$ at $95^{\circ} \mathrm{C}$, followed by addition of $200 \mu \mathrm{l}$ of a solution containing $20 \mathrm{mM}$ ATP and $0.7 \mathrm{mM}\left[{ }^{3} \mathrm{H}\right] \mathrm{cAMP}$. The particulate material was centrifuged and the ${ }^{32} \mathrm{P}$-labeled cAMP in the supernatant fraction was separated from $\left[{ }^{32} \mathrm{P}\right] \mathrm{ATP}$ over a Biorad AG-50 resin column followed by precipitation with $\mathrm{Ba}(\mathrm{OH})_{2}$ and $\mathrm{ZnSO}_{4}$ according to Krishna et al. ${ }^{16}$. Recovery of cAMP was measured using the $\left[{ }^{3} \mathrm{H}\right]$ cAMP and was usually $80-90 \%$.

\section{${ }^{3} \mathrm{HJSCH} 23390$ binding assay}

Membrane fractions were prepared as described for adenylate cyclase assays with two exceptions. Retinas were homogenized in 20 mM HEPES buffer, $\mathrm{pH} 7.8$, containing $1.2 \mathrm{mM}$ EGTA, $5 \mathrm{mM}$ $\mathrm{MgSO}_{4}$ and $0.32 \mathrm{M}$ sucrose with a Brinkman polytron for $10 \mathrm{~s}$ at setting 6 prior to centrifugation. The assay, in a volume of $1 \mathrm{ml}$, contained $\left[{ }^{3} \mathrm{H}\right] \mathrm{SCH} 23390$, unlabeled competing drug or buffer, $0.1 \%$ tartaric acid and $800 \mu \mathrm{l}$ of membranes to give a protein concentration of $0.1 \mathrm{mg} / \mathrm{ml}$. Samples were incubated for $90 \mathrm{~min}$ at $25^{\circ} \mathrm{C}$. Non-specific binding was determined in the presence of 10 $\mu \mathrm{M}$ cis-flupenthixol. The binding reaction was terminated by rapid filtration over Whatman GF/C filters and immediate rinsing 4 times with $4 \mathrm{ml}$ of ice-cold $50 \mathrm{mM}$ Tris $\mathrm{HCl}$ buffer, $\mathrm{pH} \mathrm{7.7}$. The filters were allowed to air dry for $30 \mathrm{~min}$, placed in xylene-based Aqueous Counting Scintillant (ACS) and shaken for $30 \mathrm{~min}$. Radioactivity was determined by liquid scintillation spectrophotometry.

\section{Protein measurement}

Protein was determined by the method of Lowry et al. ${ }^{17}$.

\section{Data analysis}

Statistical analysis was performed using paired Student $t$-test. $K_{\mathrm{d}}$ and $B_{\max }$ values for $\left[{ }^{3} \mathrm{H}\right] \mathrm{SCH} 23390$ binding were determined from Scatchard analysis. The data fit to a single site and linear regression was used to calculate the actual values. A possible difference in $K_{\mathrm{d}}$ or $B_{\max }$ values for $\left[{ }^{3} \mathrm{H}\right] \mathrm{SCH} 23390$ binding for control and $\mathrm{KCl}-$ treated retinas was also assessed by non-linear regression analysis using Graph PAD (ISI, Philadelphia, PA). The data were first analyzed simultaneously with the $K_{\mathrm{d}}$ and $B_{\max }$ values both constrained to be estimated as a common value between treatment groups (pooled fit). The data were then analyzed such that both parameters could vary between control and $\mathbf{K C l}$ treatment groups (separate fit). The improvement in fit produced by relaxing the constraints was assessed using the variance ratio ( $F$ statistic) derived from the residual variance (the ratio of the sum of squares of the residuals divided by the degrees of freedom) as described by Motulsky and Ransnas ${ }^{19}$. The $F$ ratio was calculated using the equation $\left.F=\left[\left(\mathrm{SS}_{\text {pool }}-\mathrm{SS}_{\text {sep }}\right) / \mathrm{df}_{\text {pool }}-\mathrm{df}_{\text {sep }}\right)\right] /\left(\mathrm{SS}_{\text {sep }} / \mathrm{df}_{\text {sep }}\right)$ where $\mathrm{SS}_{\text {pool }}=$ sum of squares of the combined fit, $\mathrm{SS}_{\text {sep }}=$ sum of squares of the separate fits, $\mathrm{df}_{\text {pool }}=$ the degrees of freedom of the combined fit and $\mathrm{df}_{\text {sep }}=$ degrees of freedom of the separate fit. The curves for competition of SKF38393 for $\left[{ }^{3} \mathrm{H}\right] \mathrm{SCH} 23390$ binding were fit to a two site model using Graph PAD. The curves were analyzed with the $K_{\mathrm{i}}$ values for the two sites estimated to be a common value and with the constraints relaxed. The improvement in fit produced by relaxing the constraints was assessed as described above.

\section{Materials}

$\left[a{ }^{32} \mathrm{P}\right] \mathrm{ATP}(30 \mathrm{Ci} / \mathrm{mmol})$ and $\left[{ }^{3} \mathrm{H}\right] \mathrm{SCH} 23390(76 \mathrm{Ci} / \mathrm{mmol})$ were obtained from Amersham Searle, Arlington Heights, IL. ATP, cAMP, PEP and BSA were purchased from Sigma Chemical Co., St. Louis, MO. GTP and pyruvate kinase were from BoehringerMannheim, Indianapolis, IN. Cis-flupenthixol was graciously donated by H. Lunbeck, A/S, Copenhagen, Denmark. SKF38393 was generously donated by Smith Kline and French Pharmaceuticals, Philadelphia, PA.

\section{RESULTS}

Following incubation with $56 \mathrm{mM} \mathrm{KCl}$, there was a significant decrease in stimulation of adenylate cyclase by $\mathrm{DA}$ in retinal membranes as compared to membranes from retinas preincubated in low potassium (Fig. 1). Kinetic analysis of enzyme activity using a Hanes plot demonstrated that there was a significant difference in the apparent $V_{\max }$ for DA in retinas treated with high $\mathrm{KCl}$, as compared to the low $\mathrm{KCl}$ control. The apparent $V_{\max }$ of the reaction decreased from $102 \pm 15 \mathrm{pmol} /$ $\mathrm{min} / \mathrm{mg}$ protein for control retinas to $71 \pm 11 \mathrm{pmol} /$ $\mathrm{min} / \mathrm{mg}$ protein for high $\mathrm{KCl}$-treated retinas $(n=5, P<$ 0.05 , two-tailed paired $t$ ). The apparent $K_{\mathrm{a}}$ value of the enzyme was not significantly different between the two groups, being $1.5(1.2-1.8)$ and $1.7(1.4-2.0) \mu \mathrm{M}$ for 


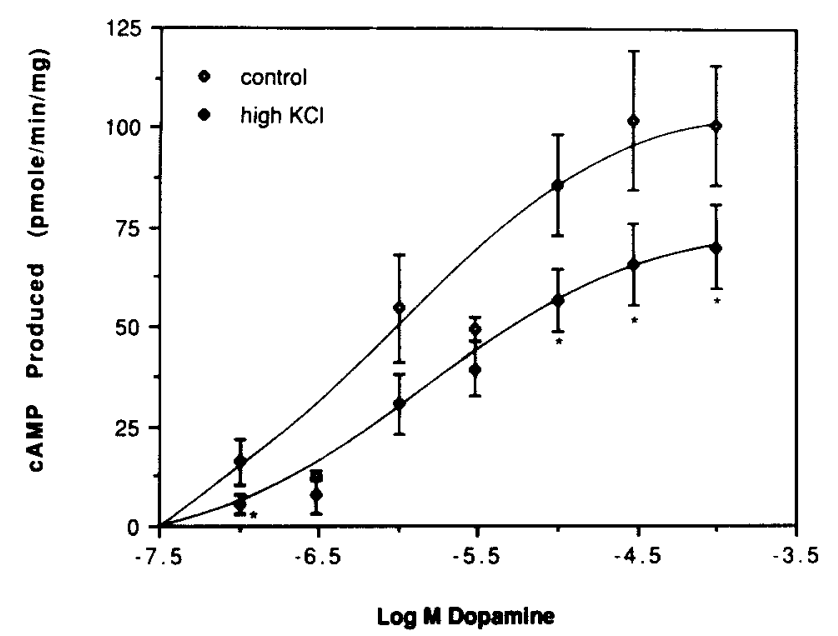

Fig. 1. DA-stimulated adenylate cyclase activity in bovine retina after preincubation with high $\mathrm{KCl}$ or under control conditions. Activation of adenylate cyclase by DA was measured in membranes prepared from retinas incubated in physiological buffer containing low or with high $\mathrm{KCl}$ as described in Methods. DA-stimulated activity was calculated as described in Methods. Adenylate cyclase activities in the presence of GTP are given in the text. Each point represents the average \pm SE of 5 separate determinations performed in triplicate. ${ }^{*} P<0.05$ for treatment as compared to control, paired $t$-test.

control and high $\mathrm{KCl}$-treated retinas, respectively. The apparent $K_{\mathrm{a}}$ values were averaged as the logarithm base 10 therefore the standard error (numbers in parentheses) is expressed as a range.

The basal adenylate cyclase activities in the control and treatment groups were not significantly different, being $59 \pm 11$ vs $47 \pm 4 \mathrm{pmol} / \mathrm{min} / \mathrm{mg}$ protein, respectively $(n$ $=5$ ). Activities measured in the presence of $1 \mu \mathrm{M} \mathrm{GTP}$ in the control and treatment groups were also not significantly different $(67 \pm 11$ vs $49 \pm 4 \mathrm{pmol} / \mathrm{min} / \mathrm{mg}$ protein, respectively $(n=5)$. The control values appear somewhat higher than treatment values due to one high

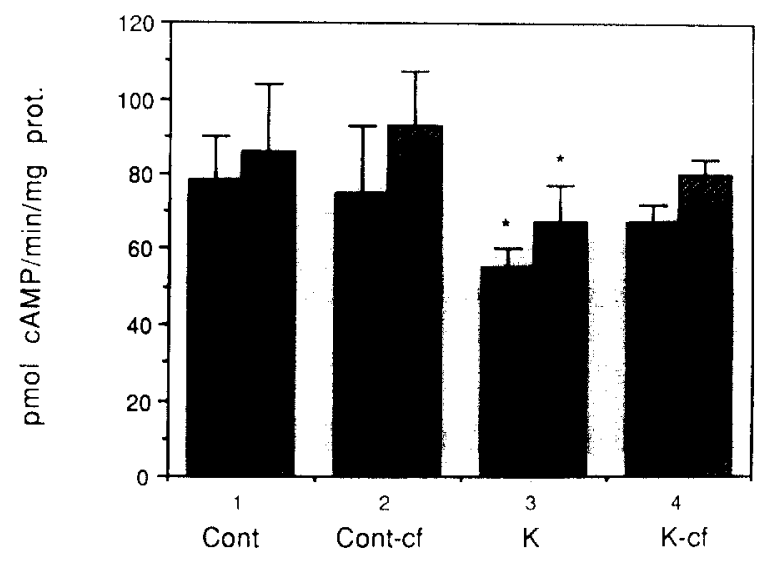

Fig. 2. Effect of $500 \mathrm{nM}$ cis-flupenthixol on potassium-induced decrease in DA-stimulated adenylate cyclase activity in bovine retina. Retinas were preincubated under control (cont) conditions or in the presence of $56 \mathrm{mM} \mathrm{KCl}(\mathrm{K})$ in the absence or presence (cont-cf, K-cf) of $500 \mathrm{nM}$ cis-flupenthixol as described in Methods. The results are shown as the DA-stimulated adenylate cyclase activity for $10 \mu \mathrm{M}$ (solid bars) and $100 \mu \mathrm{M}$ (striped bars) DA in pmol of $\mathrm{cAMP} / \mathrm{min} / \mathrm{mg}$ protein. Results are the average of 4 experiments \pm S.E. each performed in triplicate. Adenylate cyclase activities in the presence of $1 \mu \mathrm{M}$ GTP in pmol/min/mg prot. for cont, cont-cf, $\mathrm{K}$ and $\mathrm{K}$-cf groups were: $61 \pm 6,57 \pm 8,55 \pm 8$ and $39 \pm 9$, respectively. ${ }^{*} P<0.05$ as compared to cont and $\mathrm{K}$-cf conditions, paired $t$-test. ${ }^{* *} P<0.05$ as compared to cont, cont-cf, and $\mathrm{K}$-cf conditions, paired $t$-test.

control value that skewed the average.

To further determine whether the desensitization produced by depolarization was due to a release of DA, the ability of a DA receptor antagonist to block the desensitization was examined. Retinas were preincubated under low (control) and high $\mathrm{KCl}$ conditions with and without $500 \mathrm{nM}$ cis-flupenthixol. The inclusion of $500 \mathrm{nM}$ cis-flupenthixol in the preincubation blocked the $\mathrm{KCl}$ induced decrease in stimulation of adenylate cyclase by 10 and $100 \mu \mathrm{M}$ DA as shown in Fig 2. Cis-flupenthixol
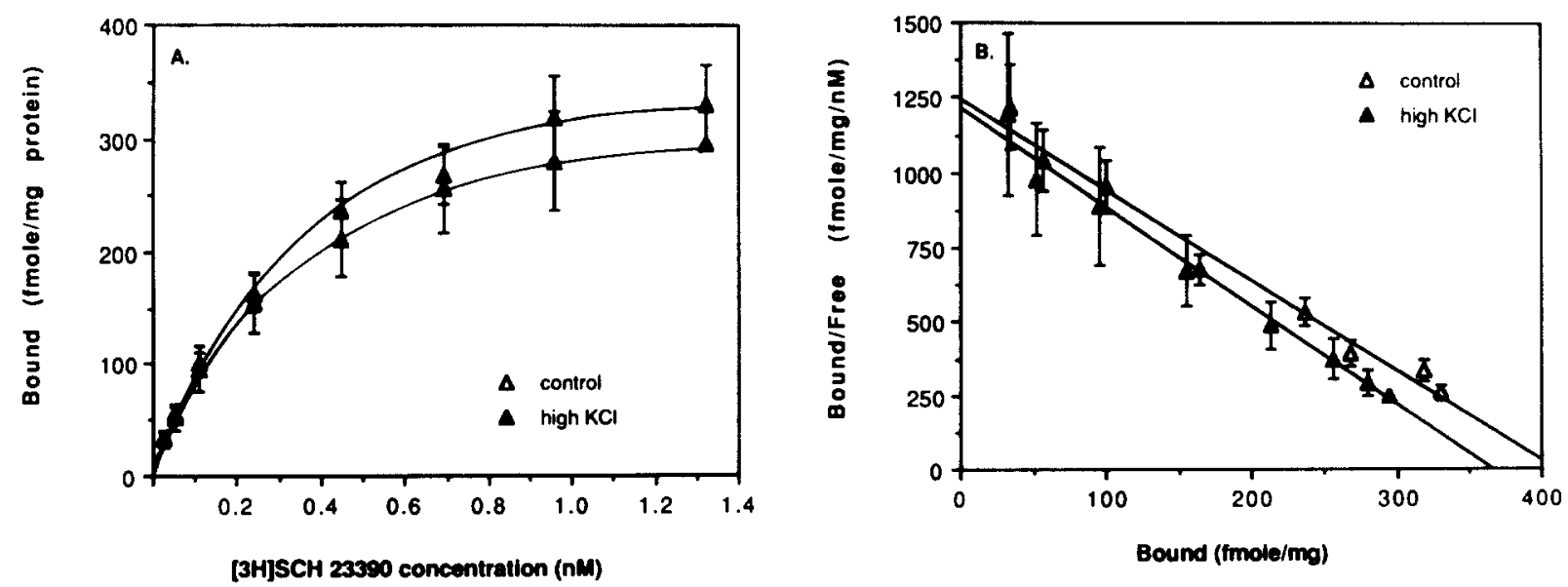

Fig. 3. Binding of $\left[{ }^{3} \mathrm{H}\right] \mathrm{SCH} 23390$ to bovine retinal membranes after preincubation under control conditions or with high $\mathrm{KCl}$. Binding of $\left[{ }^{3} \mathrm{H}\right] \mathrm{SCH} 23390$ to retinal membranes was measured as described in Methods. A: saturation curve for $\left[{ }^{3} \mathrm{H}\right] \mathrm{SCH} 23390$ binding. B: Scatchard analysis of data in $\mathrm{A}$. Each point represents the mean \pm S.E. for 5 separate experiments. Kinetic constants are given in text. 
itself had no effect on DA activation under control conditions.

The possibility that the desensitization was due to a change in number or affinity of $D_{1}$ receptors was examined by measuring the binding of a labeled antagonist to $D_{1}$ receptors on the membranes after preincubation in high $\mathrm{KCl}$ or control conditions. The level of $\mathrm{D}_{1}$ receptors in retinas was measured initially with the specific $D_{1}$ antagonist, $\left[{ }^{3} \mathrm{H}\right] \mathrm{SCH} 23390$. Saturation curves representing specific binding of $\left[{ }^{3} \mathrm{H}\right] \mathrm{SCH} 23390$ to retinal membranes after preincubation in high $\mathrm{KCl}$ or control conditions are shown in Fig. 3. The data in Fig. 3A demonstrate that there was no significant difference in the affinity or density of $D_{1}$ receptors present in retinas preincubated under control conditions or with high $\mathrm{KCl}$. Scatchard analysis (Fig. 3B) of the saturation experiments produced $B_{\max }$ values of $415 \pm 38 \mathrm{fmol} / \mathrm{mg}$ protein and $371 \pm 43 \mathrm{fmol} / \mathrm{mg}$ protein for control and high $\mathrm{KCl}$ treatment groups, respectively $(n=5)$. The $K_{\mathrm{d}}$ values for $\left[{ }^{3} \mathrm{H}\right] \mathrm{SCH} 23390$ were $0.32(0.298-0.35) \mathrm{nM}$ and 0.33 (0.27-0.40) $\mathrm{nM}$ for control and treatment groups, respectively. The $K_{\mathrm{d}}$ values were averaged as the logarithm base 10 , therefore the standard errors are given as a range. The results were also analyzed using non-linear regression analysis with the program Graph PAD. The combined saturation curves from 5 control and $5 \mathrm{KCl}-$ treated retinas were fit simultaneously with no constraints placed on the analyses. The average $B_{\max }$ values for control and treatment retinas calculated by this analysis were, in $\mathrm{fmol} / \mathrm{mg}$ protein, $435 \pm 35$ and $387 \pm 47$, respectively. It was found that the fit by non-linear least square analysis fitted with combined and separate $F$-test showed no improvement with sum of squares residuals ( $F$ $=1.09, P>0.05)$. Therefore neither the $B_{\max }$ nor $K_{\mathrm{d}}$ values for the two groups were significantly different.

Although no difference in receptor density was detected by measuring antagonist binding, it is possible that there could be a selective alteration of $D_{1}$ agonist binding

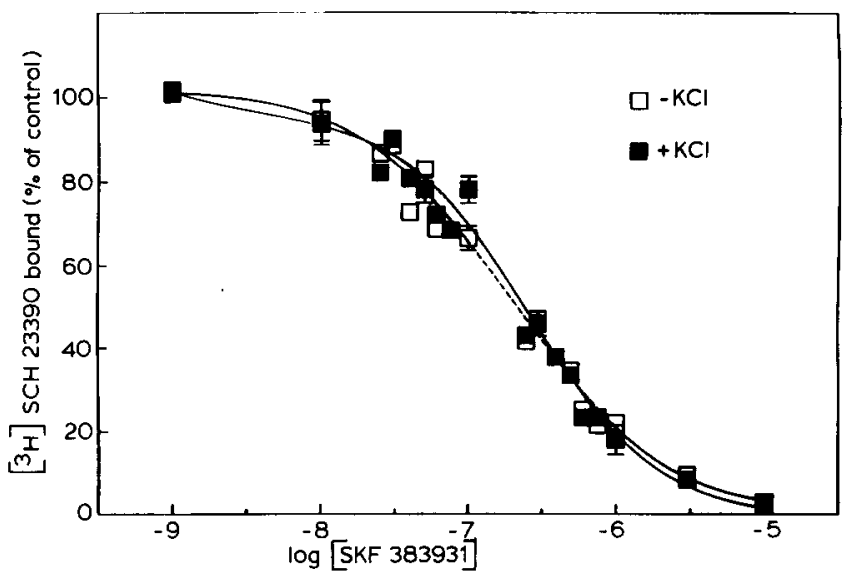

Fig. 4. Competition for $\left[{ }^{3} \mathrm{H}\right] \mathrm{SCH} 23390$ binding sites by SKF38393 following preincubation of bovine retinas with low or high $\mathrm{KCl}$. Non-specific binding was determined with $10 \mu \mathrm{M}$ cis-flupenthixol. The concentration of $\left[{ }^{3} \mathrm{H}\right] \mathrm{SCH} 23390$ was $0.15 \mathrm{nM}$. Each point represents the average of one to 3 separate experiments conducted in triplicate.

sites, which would be detected by measuring agonist competition with labeled $\left[{ }^{3} \mathrm{H}\right] \mathrm{SCH} 23390$. Competition for $\left[{ }^{3} \mathrm{H}\right] \mathrm{SCH} 23390$ binding by the $\mathrm{D}_{1}$ receptor agonist SKF38393 was measured following treatment with high $\mathrm{KCl}$ (Fig. 4). The curves were fit to a two site analysis using Graph PAD. In 3 separate experiments, no difference was found between control and treatment groups in the ability of the selective $\mathrm{D}_{1}$ agonist SKF38393 to compete for $\left[{ }^{3} \mathrm{H}\right] \mathrm{SCH} 23390$ binding sites. The $K_{\mathrm{i}}$ values for SKF38393 competition for the combined control experiments were $43 \mathrm{nM}$ and $280 \mathrm{nM}$ for the high and low affinity sites, respectively, and $40 \%$ of the sites were of high affinity. The $K_{\mathrm{i}}$ values for SKF38393 competition for the combined $\mathrm{KCl}$ treatment experiments were $2 \mathrm{nM}$ and $180 \mathrm{nM}$ for the high and low affinity sites, respectively, and $19 \%$ of the sites were of high affinity. Calculation of the variance ratio ( $F$ statistic) as described by Motulsky and Ransnas ${ }^{19}$ demonstrated that there was

\section{TABLE I}

Effect of preincubation with IBMX or dbcAMP on activation of adenylate cyclase by $100 \mu M D A$ in bovine retina

Adenylate cyclase activity is expressed as pmol of $\mathrm{cAMP} / \mathrm{min} / \mathrm{mg}$ protein produced by $100 \mu \mathrm{M} \mathrm{DA}$ above that activity in the presence of $1 \mu \mathrm{M}$ GTP. Adenylate cyclase activities in the presence of GTP, in pmol/min/mg protein fopr Expt. 1 control, $\mathrm{KCl}$, IBMX treatment and IBMX + KCl are: $31 \pm 2,34 \pm 5,48 \pm 8$ and $31 \pm 5$, respectively. Adenylate cyclase activities in the presence of GTP, in pmol/min/mg protein, for Expt. 2 are: $45 \pm 5,37 \pm 6$ and $45 \pm 5$, respectively. n.d. $=$ not determined.

\begin{tabular}{llllll}
\hline & \multicolumn{4}{l}{ DA-stimulated adenylate cyclase activity (pmol/min/mg prot.) } \\
\cline { 2 - 6 } & $n$ & Control & $56 \mathrm{mM} \mathrm{KCl}$ & Treatment & Treatment $+\mathrm{KCl}$ \\
\hline Expt. 1: 2 mM IBMX & 4 & $68 \pm 8$ & $28 \pm 8^{*}$ & $32 \pm 4^{*}$ & $41 \pm 7^{* *}$ \\
Expt. 2: 1 mM dbcAMP & 3 & $94 \pm 3$ & $75 \pm 5^{* *}$ & $80 \pm 3^{*}$ & n.d. \\
\hline
\end{tabular}

${ }^{*} P \leq 0.05$ with respect to corresponding control, paired $t$-test.

${ }^{* *} P \leq 0.05$ with respect to Expt. 2 control, unpaired $t$-test. 


\section{TABLE II}

Stimulation of adenylate cyclase activity by VIP following incubation of bovine retinas with $56 \mathrm{mM} \mathrm{KCl}$

VIP-stimulated adenylate cyclase activity is expressed as the pmol of cAMP produced $/ \mathrm{min} / \mathrm{mg}$ protein above that activity in the presence of $1 \mu \mathrm{M}$ GTP. Adenylate cyclase activities in the presence of $1 \mu \mathrm{M}$ GTP for control and $56 \mathrm{mM} \mathrm{KCl}$ preincubations are: 55 and 42 $\mathrm{pmol} / \mathrm{min} / \mathrm{mg}$ protein, respectively. Results are the average of 2 experiments, performed in triplicate, that differed less than $10 \%$.

\begin{tabular}{lll}
$\begin{array}{l}\text { VIP concentration } \\
(\mathrm{mM})\end{array}$ & $\begin{array}{l}\text { VIP-stimulated adenylate cyclase activity } \\
(\text { pmol/min/mg prot.) }\end{array}$ \\
\cline { 2 - 3 } & Control & $56 \mathrm{mM} \mathrm{KCl}$ \\
\hline 1 & 29 & 15 \\
10 & 34 & 24 \\
100 & 75 & 31 \\
\hline
\end{tabular}

no improvement in fit produced by relaxing the constraints between the control and treatment values. Therefore there was no significant difference in agonist binding to $\left[{ }^{3} \mathrm{H}\right] \mathrm{SCH} 23390$ binding sites between the control and $\mathrm{KCl}$ treatment groups $(F=0.68, p \geqslant 0.05)$.

The lack of change in $D_{1}$ receptor binding suggested that potassium depolarization could have produced a heterologous desensitization which is partially mediated by cAMP $^{27}$. To examine this possibility, retinas were preincubated with IBMX, a phosphodiesterase inhibitor, and dibutyryl cAMP. As shown in Table I, there was a significant decrease in $\mathrm{pmol}$ of cAMP produced $/ \mathrm{min} / \mathrm{mg}$ protein in retinas preincubated under control conditions with $2 \mathrm{mM}$ IBMX as compared to retinas preincubated solely under control conditions. Preincubation of retinas with $\mathrm{KCl}+\mathrm{IBMX}$ produced no greater desensitization than that induced by either agent alone. Similarly, preincubation of retinas in the presence of $1 \mathrm{mM}$ dibutyryl cAMP also produced a desensitization of DA-stimulated adenylate cyclase activity. Neither IBMX nor dibutyryl cAMP altered the basal or GTP-stimulated adenylate cyclase activity in any group.

We then determined whether the desensitization produced by potassium depolarization was specific for the $D_{1}$ DA receptor. Following incubation of retinas with control or high potassium buffer, the stimulation of adenylate cyclase activity by VIP was measured. As shown in Table II, the stimulation of adenylate cyclase activity was decreased in retinas preincubated with high $\mathrm{KCl}$ at each concentration of VIP measured.

\section{DISCUSSION}

We have found that potassium depolarization elicited a rapid desensitization of $D_{1}$ receptor stimulation of adenylate cyclase activity in bovine retinas. It is likely that the DA receptor desensitization was mediated by a release of DA from retinal neurons. It has been shown that incubation of retinas, including calf retina, with potassium increases cAMP content in the retina and this can be blocked with DA receptor antagonists ${ }^{5.28}$. In this study it was found that the potassium-induced desensitization of the DA-stimulated adenylate cyclase activity could be blocked with cis-flupenthixol, a DA receptor antagonist.

The desensitization was manifested by a decrease in apparent $V_{\max }$ for DA-stimulated adenylate cyclase activity with no change in affinity for DA. There was no measurable change in DA receptor density or agonist affinity as determined by binding of the antagonist $\left[{ }^{3} \mathrm{H}\right] \mathrm{SCH} 23390$ or by agonist competition for antagonist binding. The simplest explanation for the results is that potassium releases $D A$, which activates postsynaptic $D_{1}$ receptor and brings about a desensitization of that receptor. Another possible explanation for the results is that $\mathrm{KCl}$ would induce an increase in $\mathrm{D}_{2}$ receptor activity, which inhibits adenylate cyclase ${ }^{29}$, causing a resultant decrease in $D_{1}$-mediated stimulation. This would require that $D_{1}$ and $D_{2}$ receptors be located on the same postsynaptic membrane and be functionally coupled. Using autoradiography, Brann and Young ${ }^{3}$ found that $D_{2}$ receptor-specific ligands densely labeled rods in bovine retina but there was very little specific labeling in the inner nuclear or inner plexiform layers. $D_{2}$ receptors that are present in the inner layers of the bovine retina have been shown to modulate release of DA from cells ${ }^{25}$. Pachter and $\mathrm{Lam}^{21}$ found that neither $\mathrm{D}_{2}$ agonists nor antagonists altered DA-stimulated adenylate cyclase activity in rabbit retinal homogenates. Qu et al. ${ }^{24}$, however, recently reported that inhibition of adenylate cyclase by $\mathrm{DA}$ and $\mathrm{D}_{2}$ agonists could be measured in intact rat retina after preincubation with $\mathrm{SCH} 23390$. These results suggest that $D_{1}$ and $D_{2}$ receptors could be functionally coupled on the rat retinal membrane. If this is true in bovine retina, the $\mathrm{KCl}$-mediated release of $\mathrm{DA}$, while initially activating $D_{2}$ receptors, would probably result in a desensitization of $D_{2}$ receptors thereby decreasing the $\mathrm{D}_{2}$ activity upon subsequent measurement in an assay. Further, preliminary experiments using SKF38393, a selective $D_{1}$ agonist, instead of DA also demonstrated the desensitization. The experiments demonstrating the blockade of the $\mathrm{KCl}$-induced desensitization with cisflupenthixol do not answer this question since cisflupenthixol has nearly equal affinity for $D_{1}$ and $D_{2}$ receptors. The studies of VIP activation and IBMX- and dbcAMP-induced desensitization coupled with the lack of change of $D_{1}$ receptor binding, however, strongly suggest that the desensitization induced by potassium is heterologous in nature. In heterologous desensitization, no change is found in receptor binding characteristics, but 
there is a decrease in activation of adenylate cyclase by the desensitizing hormone/neurotransmitter and other neurotransmitters that are coupled to the common adenylate cyclase catalytic subunit ${ }^{8,27}$. There may be a slight decrease in activity of agents that act at Gs such as GTP. In most of our experiments, stimulation by GTP was unaltered by $\mathrm{KCl}$ treatment, although in some assays (see legend to Fig. 2) there were decreases in GTP stimulation. In this study, we found a decrease in stimulation of adenylate cyclase by both DA and VIP in retinas after preincubation in high potassium. There is some evidence that DA and VIP receptors can exist on the same cells in retina. Pachter and $\mathrm{Lam}^{21}$ have found that both DA and VIP stimulate adenylate cyclase in homogenates of rabbit retina in a non-additive manner. VIP activation of adenylate cyclase has also been demonstrated in isolated horizontal cells of fish retina that contain DA receptors ${ }^{33}$. The potassium-induced desensitization could be mimicked by IBMX and dibutyryl cAMP suggesting that a cAMP-dependent phosphorylation partially mediates the desensitization as has been demonstrated for heterologous desensitization ${ }^{27}$ of the $\beta$-adrenergic receptor.

The preincubation of retinas with high concentrations of potassium could mimic the effect of light on the retinas. Light has been shown to release DA from its neurons in retinas ${ }^{2,15}$. It has been demonstrated that the light-stimulated release of DA in rabbit retina is similar to that evoked by membrane depolarization by high potassium concentrations or electric current ${ }^{2,20}$. Light has also been shown to regulate $D A D_{1}$ receptor activity in mammalian retinas. We have previously shown that preincubation of bovine retinas for $20 \mathrm{~min}$ under light conditions produced a desensitization of DA-stimulated adenylate cyclase as compared to those preincubated under dark conditions ${ }^{6}$. The light-induced desensitization could be mimicked by preincubation with DA. Porceddu et al. ${ }^{22}$ found a greater activation of adenylate cyclase activity by DA in retinas from rats subjected to $4 \mathrm{~h}$ of dark adaptation as compared to light-adapted animals. In

\section{REFERENCES}

1 Ames, A. and Pollen, D.A., Neurotransmission in central nervous tissue: a study of isolated rabbit retina, $J$. Neurophysiol., 32 (1969) 424-442.

2 Boatright, J.H., Hoel, M.J. and Iuvone, P.M., Stimulation of endogenous dopamine release and metabolism in amphibian retina by light- and $\mathrm{K}^{+}$-evoked depolarization, Brain Research, 482 (1989) 164-168.

3 Brann, M.R. and Young, W.S. III, Dopamine receptors are located on rods in bovine retina, Neurosci. Lett., 69 (1986) 221-226.

4 Brown, J.H. and Makman, M.H., Stimulation by dopamine of adenylate cyclase in retinal homogenates and of adenosine$3^{\prime}, 5^{\prime}$-cyclic monosphosphate formation in intact retina, Proc. contrast to our results, they found an increase in the density of $\left[{ }^{3} \mathrm{H}\right] \mathrm{SCH} 23390$ binding in the retinas of dark-adapted rats which corresponded with the increase in DA stimulation of the enzyme. Our studies of desensitization induced by light and potassium involved very short-term treatments with these agents. Therefore, a rapid desensitization of DA receptors in the retina may not involve changes in receptor density or binding characteristics while changes in these parameters do occur after longer-term treatments.

Electrophysiological studies in retina suggest that one function of the dopaminergic system in retina may be to modulate the response of ganglion cells to light. It has been shown that DA affects the electrophysiological properties of ganglion cells in cat and rabbit retina ${ }^{1}$ ${ }^{10-12,18,30}$. Iontophoresis of DA or its antagonists have been found to change the spontaneous activity of both on-center and off-center ganglion cells or only off-center cells. DA antagonists potent at $D_{1}$ receptors can reduce or abolish the response of antagonist surround in rabbit retinal ganglion cells while more specific $D_{2}$ antagonists had little effect ${ }^{11}$. A rapid desensitization in DA-sensitive adenylate cyclase activity, in response to light, may be one way in which dopaminergic neurons modulate the sensitivity of ganglion cells to light. This method would provide a quick and effective modulation of ganglion cell input that would not necessitate a change in receptor number. Direct synapses from dopaminergic amacrine cells onto ganglion cells have not been identified. In cat retina, however, dopaminergic amacrine cells synapse on AII amacrine cells ${ }^{23}$ which output directly on off-center ganglion cell dendrites ${ }^{13,14}$. Therefore dopaminergic neurons may exert their influence on ganglion cells indirectly through the AII amacrine cells by a $D_{1}$ receptormediated response that is under tight dopaminergic regulation.

Acknowledgements. This work was supported by National Institute of Mental Health Grants MH36044 and MHZ09291 (J.M.A.). J.M.A. received partial support from the Training Grant EY07022 from the National Eye Institute.

Natl. Acad. Sci. U.S.A., 69 (1972) 539-543.

5 Dowling, J.E. and Watling, K.J., Dopaminergic mechanisms in the teleost retina. II. Factors affecting the accumulation of cyclic AMP in pieces of intact carp retina, $J$. Neurochem., 36 (1984) $569-579$

6 Gnegy, M.E., Muirhead, N. and Harrison, J.K., Regulation of calmodulin- and dopamine-stimulated adenylate cyclase activities by light in bovine retina, J. Neurochem., 42 (1984) 1632-1640.

7 Haggendal, J. and Malmfors, T., Evidence of dopaminecontaining neurons in the retina of rabbits, Acta Physiol. Scand., 64 (1965) 58-66.

8 Harden, T.K., Agonist-induced desensitization of the $\beta$-adrenergic receptor-linked adenylate cyclase, Pharmacol. Rev., 35 (1983) 5-32. 
9 Hensler, J.G., Cotterell, D.J. and Dubocovich, M.L., Pharmacological and biochemical characterization of the $D_{1}$ dopamine receptor mediating acetylcholine release in rabbit retina, $J$. Pharmacol. Exp. Ther., 342 (1987) 857-867.

10 Ikeda, H., Robbins, J. and Wakakuwa, K., Evidence for dopaminergic innervation on kitten retinal ganglion cells, Dev. Brain Res., 35 (1987) 83-89

11 Jensen, R.J. and Daw, N.W., Effects of dopamine antagonists on receptive fields of brisk cells and directionally selective cells in the rabbit retina, J. Neurosci., 4 (1984) 2972-2985.

12 Jensen, R.J. and Daw, N.W., Effects of dopamine and its agonists and antagonists on the receptive field properties of ganglion cells in the rabbit retina, Neuroscience, 17 (1986) $837-855$.

$13 \mathrm{Kolb}, \mathrm{H}$., The inner plexiform layer in the retina of the cat: electron microscope observations, $J$. Neurocytol, 8 (1979) 295-329.

14 Kolb, H. and Wang, H.H., The distribution of photoreceptors. dopaminergic amacrine cells and ganglion cells in the retina of the north american opposum, Vision Res., 25 (1985) 1207-1221.

15 Kramer, S.G., Dopamine: a retinal neurotransmitter. I. Retinal uptake, storage and light stimulated release of ${ }^{3} \mathrm{H}$-dopamine in vivo, Invest. Ophthamol. Vision Res., 10 (1971) 438-452.

16 Krishna, G., Weiss, B. and Brodie, B.B., A simple, sensitive method for the assay of adenyl cyclase. J. Pharmacol. Exp. Ther., 163 (1968) 379-385.

17 Lowry, O.H., Rosebrough, N.J., Farr, A.L. and Randall, R.J., Protein measurement with the Folin phenol reagent, J. Biol. Chem., 193 (1951) 265-275.

18 Maguire, G.W. and Smith, E.L. III, Cat retinal ganglion cell receptive-field alterations after 6-hydroxydopamine induced dopaminergic amacrine cell lesions, $J$. Neurophysiol., 53 (1985) 1431-1443.

19 Motulsky, H.J. and Ransnas, L.A., Fitting curves to data using non-linear regression: a practical and non-mathematical review, FASEB J., 1 (1987) 365-374.

20 Nowak, J.Z., The isolated retina as a model of the CNS in pharmacology, Trends Pharmacol. Sci., 9 (1988) 80-82.

21 Pachter, J.A. and Lam, D.M., Interactions between vasoactive intestinal peptide and dopamine in the rabbit retina: stimulation of a common adenylate cyclase. J. Neurochem., 46 (1986) 257-264.

22 Porceddu, M.L., De Montis, G., Mele, S., Ongini, E. and Biggio, $G ., D_{1}$ dopamine receptors in the rat retina: effect of dark adaptation and chronic blockade by SCH 23390, Brain Research, 424 (1987) 264-271.

23 Pourcho, R., Dopaminergic amacrine cells in the cat retina, Brain Research, 252 (1982) 101-109.

$24 \mathrm{Qu}, \mathrm{C}$-X., Fertel, R., Neff, N. and Hadjiconstantinou, M., Pharmacological characterization of rat retinal dopamine receptors, J. Pharmacol. Exp. Ther, 248 (1989) 621-625.

25 Reading, H.W., Dopaminergic receptors in bovine retina and their interaction with thryotropin-releasing hormone, $J$. Neurochem., 41 (1983) 1587-1959.

26 Schorderet, M., Pharmacological characterization of the dopamine-mediated accumulation of cyclic AMP in intact retina of rabbit, Life Sci., 20 (1977) 1741-1748.

27 Sibley, D.R., Benovic, J.L., Caron, M.G. and Lefkowitz, R.J., Regulation of transmembrane signaling by receptor phosphorylation, Cell, 48 (1987) 913-922.

28 Sovilla, J.-Y. and Schorderet, M., L-DOPA mediated accumulation of cyclic AMP in isolated rabbit retina in vitro. Effects of light and/or pharmacological factors, Life Sci., 31 (1982) 2081-2092.

29 Stoof, J. and Kebabian, J.W., Two dopamine receptors: Biochemistry, physiology and pharmacology, Life Sci., 35 (1984) 2281-2296.

30 Straschill, M. and Perwein, J., The inhibition of retinal ganglion cells by catecholamines and $\gamma$-aminobutyric acid, Pflugers Arch., 312 (1969) 45-54.

31 Teranishi, T.. Negishi, K. and Kato, S., Dopamine modulates $S$-potential amplitude and dye-coupling between external horizontal cells in carp retina, Nature (Lond.), 301 (1983) 243-246.

32 Their, P. and Adler, V., Action of iontophoretically applied dopamine on cat retinal ganglion cells, Brain Research, 292 (1984) 109-121.

33 Watling, K.J. and Dowling, J.E., Effects of vasoactive intestinal peptide and other peptides on cyclic AMP accumulation in intact pieces and isolated horizontal cells of the teleost retina, $J$. Neurochem., 41 (1983) 1205-1213. 